\title{
Fallopian Tube Cancer pT1a TNM Finding v7
}

National Cancer Institute

\section{Source}

National Cancer Institute. Fallopian Tube Cancer pT 1a TNM Finding v7. NCI Thesaurus. Code C89671.

Fallopian tube cancer with tumor limited to one tube, without penetrating the serosal surface; no ascites. (from AJCC 7th Ed.) 